\title{
Preparation and characterization of solid-state sintered aluminum-doped zinc oxide with different alumina contents
}

\author{
YU-HSIEN CHOU*, J L H CHAU, W L WANG, C S CHEN, S H WANG and C C YANG \\ Nanopowder and Thin Film Technology Centre, ITRI-South, Industrial Technology Research Institute, Tainan 70955, \\ Taiwan
}

MS received 23 August 2010; revised 1 March 2011

\begin{abstract}
Aluminum-doped zinc oxide (AZO) ceramics with 0-2.5 wt.\% alumina $\left(\mathrm{Al}_{2} \mathrm{O}_{3}\right)$ content were prepared using a solid-state reaction technique. It was found that $\mathrm{AZO}$ grains became finer in size and more irregular in shape than undoped $\mathrm{ZnO}$ as the $\mathrm{Al}_{2} \mathrm{O}_{3}$ content increased. Addition of $\mathrm{Al}_{2} \mathrm{O}_{3}$ dopant caused the formation of phase transformation stacking faults in $\mathrm{ZnO}$ grains. The second phase, $\mathrm{ZnAl}_{2} \mathrm{O}_{4}$ spinel, was observed at the grain boundaries and triple junctions, and inside the grains. In this study, a 3-inch circular $\mathrm{Al}_{2} \mathrm{O}_{3}(2 \mathrm{wt}$ \% $\%$-doped $\mathrm{ZnO}$ ceramic target sintered at $1500^{\circ} \mathrm{C}$ for $6 \mathrm{~h}$ has a relative density of $99.8 \%$ with a resistivity of $1.8 \times 10^{-3} \Omega-\mathrm{cm}$. The AZO film exhibits optical transparency of $90.3 \%$ in the visible region and shows an electrical resistivity of $2.5 \times 10^{-3} \Omega-\mathrm{cm}$.
\end{abstract}

Keywords. $\mathrm{AZO}$ target; $\mathrm{ZnAl}_{2} \mathrm{O}_{4}$ spinel; resistivity; $\mathrm{AZO}$ thin film.

\section{Introduction}

Transparent conducting oxides (TCOs) have received considerable attention in recent years due to their good transparency and high electrical conductivity. They have broad range of applications such as transparent electrodes in solar cells and liquid crystal displays (LCDs) (Sharma and Exarhos 1995). Most of the TCOs are based on indium oxide $\left(\mathrm{In}_{2} \mathrm{O}_{3}\right)$, zinc oxide $(\mathrm{ZnO})$, tin oxide $\left(\mathrm{SnO}_{2}\right)$, and their mixed compounds (Chopra et al 1983; Coutts et al 2000).

$\mathrm{ZnO}$ is naturally an $n$-type semiconductor material. Due to its wide direct bandgap $(\sim 3.3 \mathrm{eV})$, its transmittance in the visible region is extremely high (Chopra et al 1983). $\mathrm{ZnO}$ has attracted interest as an alternative transparent conducting material to indium tin oxide (ITO) because of its (i) low cost, (ii) low growth temperature, (iii) non-toxicity, and (iv) easy adjustment of conductivity by adding impurities, such as Al, Sb and Mn (Han et al 2001a; Zhang et al 2006). Many techniques have been developed for the deposition of Al-doped $\mathrm{ZnO}$ (AZO) thin films, e.g. chemical vapour deposition (Tominaga et al 1999), wet-coating (Chatelon et al 1997), and RF-magnetron sputtering (Jeong et al 2003; Ben Ayadi et al 2008). Sputtering is a mature technology and has been extensively used for today's display applications. For the deposition of a high quality AZO thin film on a substrate via sputtering, a target with high sintering density is required.

In this work, preparation of high quality AZO targets doped with $0-2.5$ wt.\% alumina $\left(\mathrm{Al}_{2} \mathrm{O}_{3}\right)$ content using a solid-state reaction method was investigated. We studied the

*Author for correspondence (yuhsienchou@itri.org.tw) effects of $\mathrm{Al}_{2} \mathrm{O}_{3}$ dopant on the electrical resistivity, densification, and grain growth. A dense and low electrical resistivity of AZO $\left(\mathrm{Al}_{2} \mathrm{O}_{3}: 2\right.$ wt.\%) target with a diameter of 3 inch was used for the deposition. The transparent conducting thin film was deposited at room temperature by RFmagnetron sputtering. The structure, optical and electrical properties of the sputtered AZO thin film were analysed by X-ray diffraction, UV-visible spectrum and Hall effect measurement, respectively.

\section{Experimental}

The Al-doped $\mathrm{ZnO}$ ceramics was synthesized via solidstate reaction of $\mathrm{ZnO}$ (99.9\%, Aldrich, Milwaukee, WI) and $\mathrm{Al}_{2} \mathrm{O}_{3}$ (99.9\%, Showa, Tokyo, Japan) powders. The mean particle sizes of $\mathrm{ZnO}$ and $\mathrm{Al}_{2} \mathrm{O}_{3}$ powders are $75 \mu \mathrm{m}$ and $40 \mathrm{~nm}$, respectively. The $\mathrm{ZnO}$ powders were thoroughly mixed with different amounts of $\mathrm{Al}_{2} \mathrm{O}_{3}$ by ball-milling with ethanol using yttria-stabilized $\mathrm{ZrO}_{2}$ (YSZ) balls in a polyethylene (PE) bottle for $24 \mathrm{~h}$. The amounts of $\mathrm{Al}_{2} \mathrm{O}_{3}$ dopant in the samples were $0,1.5,2.0$, and $2.5 \mathrm{wt} . \%$. The mixed slurry and YSZ balls were separated by sieving through $74 \mu \mathrm{m}$ mesh, and slurry was put into the oven to remove the solvent. After drying at $100^{\circ} \mathrm{C}$ for $24 \mathrm{~h}$, powders were ground using an agate mortar and pestle and deagglomerated by sieving through a $37 \mu \mathrm{m}$ mesh. The powders were then die-pressed into discs of $12 \mathrm{~mm}(\phi)$ and $3 \mathrm{~mm}$ thick using a WC-inserted steel die at a uniaxial pressure of $40 \mathrm{MPa}$. The green density of the compacts was around $49 \pm 1 \%$ calculated from the weight and dimensions of the green compacts. 
Table 1. Sputtering parameters of deposited AZO thin film.

\begin{tabular}{ll}
\hline Sputtering parameters & Conditions \\
\hline Power (RF) & 200 \\
Base pressure & $3 \times 10^{-6} \mathrm{Torr}$ \\
Working pressure & $5 \mathrm{~m} \mathrm{Torr}$ \\
Substrate (temperature) & Room temp. \\
Target to substrate distance & $7 \mathrm{~cm}$ \\
Ar flow & $20 \mathrm{sccm}$ \\
Film thickness & about $600 \mathrm{~nm}$ \\
\hline
\end{tabular}

The discs were then sintered in air at $1500^{\circ} \mathrm{C}$ for $6 \mathrm{~h}$ with a heating and cooling rate of $5^{\circ} \mathrm{C} / \mathrm{min}$. The as-sintered bulk density was measured by the Archimedes method. After mechanical grinding, sintered samples were then oxide polished to $\sim 50 \mathrm{~nm}$ surface roughness. Polished sections were chemically etched in a $5 \% \mathrm{HCl}$ solution to delineate grains and domain boundaries. The morphologies of AZO powders and microstructures of the sintered bulk were observed using a field-emission gun SEM (JEOL ${ }^{\mathrm{TM}}$ 6330, Tokyo, Japan).
Transmission electron microscopy (TEM, JEOL ${ }^{\mathrm{TM}}$ AEM 3010, Tokyo, Japan) was performed to observe the secondary phase and microstructure of sintered specimens. The crystalline phases of sintered samples were identified via X-ray diffractometry (XRD) using a Siemens D5000 diffractometer (Karlsruhe, Germany), with $\mathrm{Cu} K \alpha_{1+2}$ radiation operating at $40 \mathrm{kV} / 30 \mathrm{~mA}$.

A 3-inch circular sputtering target made by 2 wt.\% alumina doped $\mathrm{ZnO}$ was used for thin film deposition. The as-prepared powder was disc-formed into a diameter of $100 \mathrm{~mm}(\phi)$ using a uniaxial pressure of $40 \mathrm{MPa}$. The green density was further improved to $57 \pm 0.6 \%$ after conducting cold isotatic pressing (CIP) of the compact powders with a pressure of $300 \mathrm{MPa}$. Then, the disc was sintered with the same sintering condition as previously described. The AZO transparent conductive thin films were deposited on the glass substrates (EAGLE ${ }^{2000}$, Corning) by an RF-magnetron sputtering system. The distance between sputter target and substrate was kept at $7 \mathrm{~cm}$ to ensure uniformity of AZO films. The sputtering conditions are listed in table 1. Hall measurement (Lake Shore 7500/9500 Series Hall System) was employed to measure the resistivity, carrier density and Hall
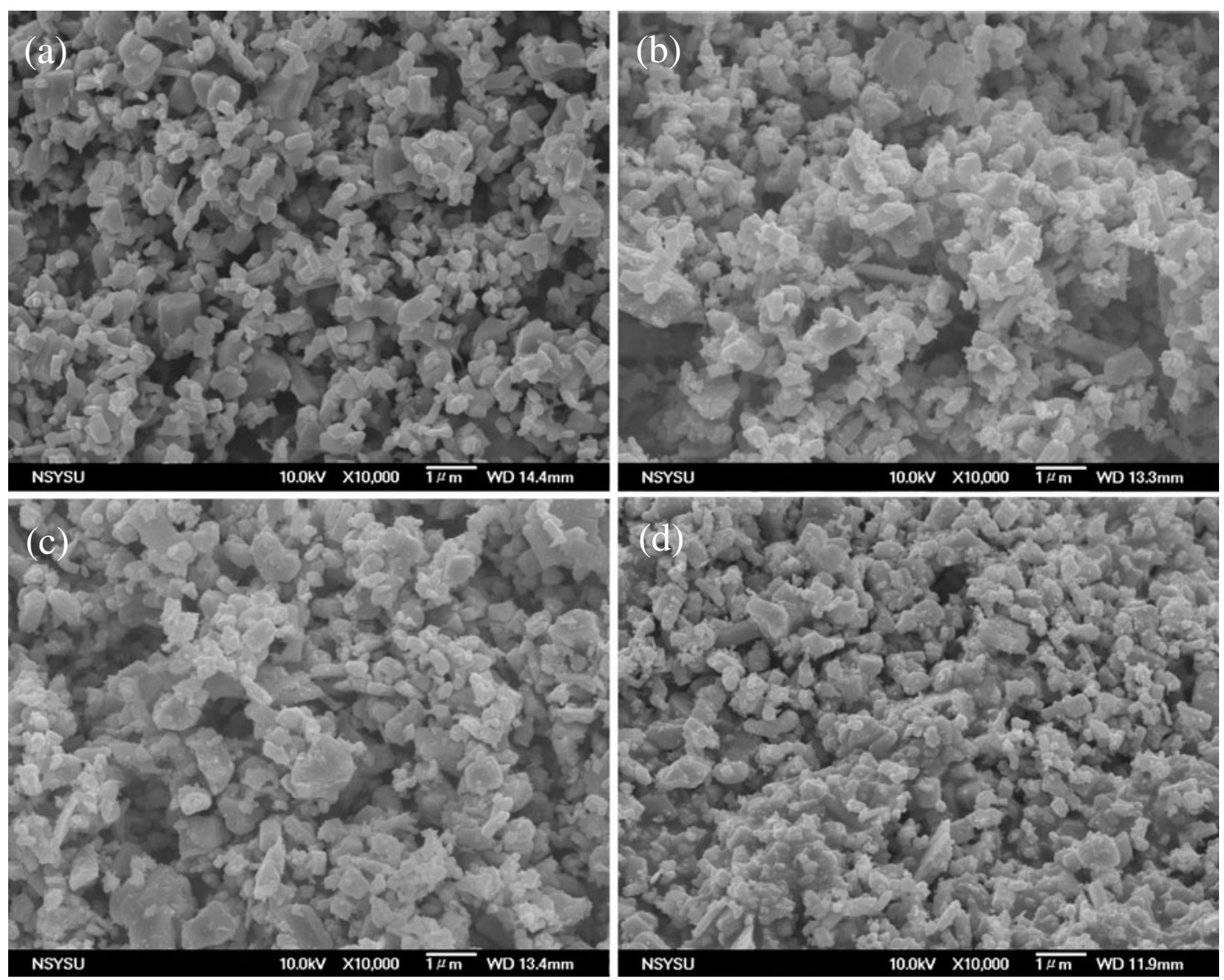

Figure 1. FE-SEM images of as-milled powders: (a) pure $\mathrm{ZnO}$, (b) doped, $\mathrm{Al}_{2} \mathrm{O}_{3}=1.5 \mathrm{wt} \%$, (c) doped, $\mathrm{Al}_{2} \mathrm{O}_{3}=$ $2 \mathrm{wt} \%$ and (d) doped, $\mathrm{Al}_{2} \mathrm{O}_{3}=2 \cdot 5 \mathrm{wt} \%$. 
mobility of $\mathrm{Al}_{2} \mathrm{O}_{3}$ doped $\mathrm{ZnO}$ bulk and thin film specimens at $25^{\circ} \mathrm{C}$. The optical transmittance of AZO films was measured using a Shimadzu UV 2100 double-beam spectrophotometer.

\section{Results and discussion}

\subsection{Preparation and characterization of AZO powder and sintering bulks}

Figure 1 (SEM) shows surface morphology of the as-milled $\mathrm{ZnO}$ and $\mathrm{ZnO}$ with $\mathrm{Al}_{2} \mathrm{O}_{3}$ contents of $1 \cdot 5,2 \cdot 0$, and 2.5 wt.\% powders. We observed that the shape and particle size were independent of $\mathrm{Al}_{2} \mathrm{O}_{3}$ contents according to SEM analysis. The average particles sizes range from $0 \cdot 2-1 \cdot 3 \mu \mathrm{m}$.

Microstructures of the $\mathrm{ZnO}-\mathrm{Al}_{2} \mathrm{O}_{3}$ system with various $\mathrm{Al}_{2} \mathrm{O}_{3}$ contents sintered at $1500^{\circ} \mathrm{C}$ for $6 \mathrm{~h}$ are depicted in figure 2. Figure 2(a) shows the sintered bulk of undoped $\mathrm{ZnO}$, which exhibits equiaxed grains and normal grain distribution. Abnormal grain growth was not detected in those specimens. The grain size ranges from 15-30 $\mu \mathrm{m}$. Figures 2(b)-(d) indicate that the grain size became finer and more irregular in shape when $\mathrm{Al}_{2} \mathrm{O}_{3}$ was added. The grain size ranges of $1.5,2.0$, and 2.5 wt. $\% \mathrm{Al}_{2} \mathrm{O}_{3}$ doped specimens were 10-20 $\mu \mathrm{m}, 10-15 \mu \mathrm{m}$, and 5-10 $\mu \mathrm{m}$, respectively. As shown in figures 2(b)-(d), there were many small grains observed at grain boundaries or grain triple junctions, and also inside the grain, as indicated by solid arrows. Chemical composition (at.\%) of the small grains determined by EDS revealed that they were, in fact, the $\mathrm{ZnAl}_{2} \mathrm{O}_{4}$ spinel second phase $(\mathrm{Zn}: \mathrm{Al}: \mathrm{O}=15 \cdot 54: 30 \cdot 62: 53 \cdot 84)$. The phenomena of grain growth inhibition which occurred in the $\mathrm{Al}_{2} \mathrm{O}_{3}$ doped specimens was attributed to the formation of $\mathrm{ZnAl}_{2} \mathrm{O}_{4}$ second phase, which leads to particle drag effects and reduces the driving force of boundary mobility (Rahaman 1995; Han et al 2001b).

Figures 3(a)-(d) show the XRD patterns of pure $\mathrm{ZnO}$ and $\mathrm{Al}_{2} \mathrm{O}_{3}$-doped $\mathrm{ZnO}$ of $1.5,2 \cdot 0$, and 2.5 wt. $\%$ contents, respectively. The second phase of cubic $\mathrm{ZnAl}_{2} \mathrm{O}_{4}$ spinel (indicated by triangle symbol) was present in the doped $\mathrm{ZnO}$ specimens. When the $\mathrm{Al}_{2} \mathrm{O}_{3}$ content was raised from $1.5-2.5 \mathrm{wt} \%$, the relative peak intensity of $\mathrm{ZnAl}_{2} \mathrm{O}_{4}$ spinel phase increased. The ratios of peak intensities of $\mathrm{ZnAl}_{2} \mathrm{O}_{4}$ (101)/ZnO (101) are about $0.023,0.032$, and 0.055 as the $\mathrm{Al}_{2} \mathrm{O}_{3}$ amount increases from $1.5-2.0$ and $2.5 \mathrm{wt} . \%$, respectively. A representative TEM bright-field image is given in
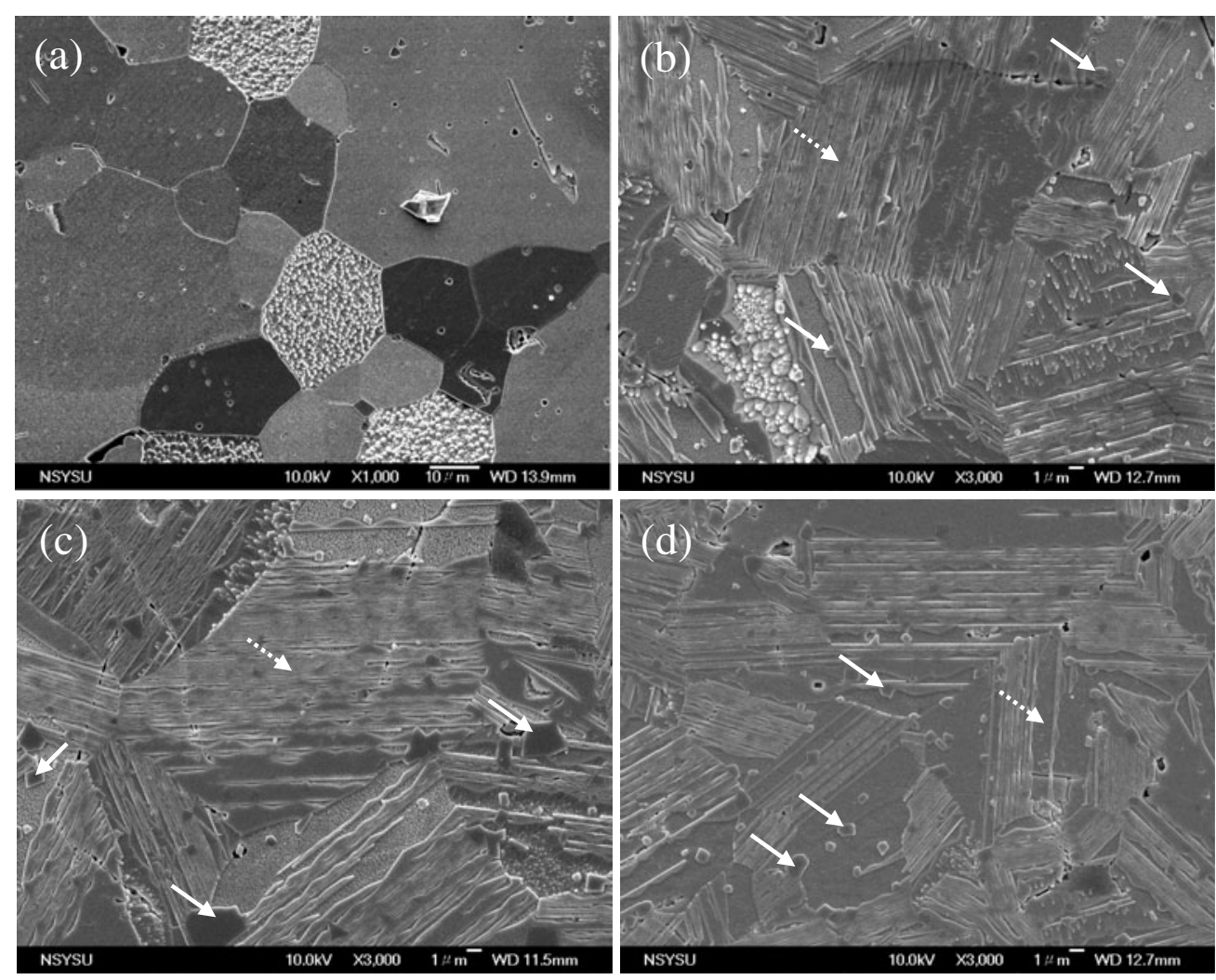

Figure 2. FE-SEM plane-view image of surface morphologies in the $\mathrm{ZnO}_{-} \mathrm{Al}_{2} \mathrm{O}_{3}$ system sintered at $1500^{\circ} \mathrm{C}$ for $6 \mathrm{~h}$ : (a) pure $\mathrm{ZnO}$; (b) doped, $\mathrm{Al}_{2} \mathrm{O}_{3}=1.5 \mathrm{wt} \%$; (c) doped, $\mathrm{Al}_{2} \mathrm{O}_{3}=2 \mathrm{wt} \%$; (d) doped, $\mathrm{Al}_{2} \mathrm{O}_{3}=2 \cdot 5 \mathrm{wt} \%$. (The solid arrow indicates the $\mathrm{ZnAl}_{2} \mathrm{O}_{4}$ spinel second phase and the dotted arrow indicates the $\mathrm{ZnO}$ matrix). 


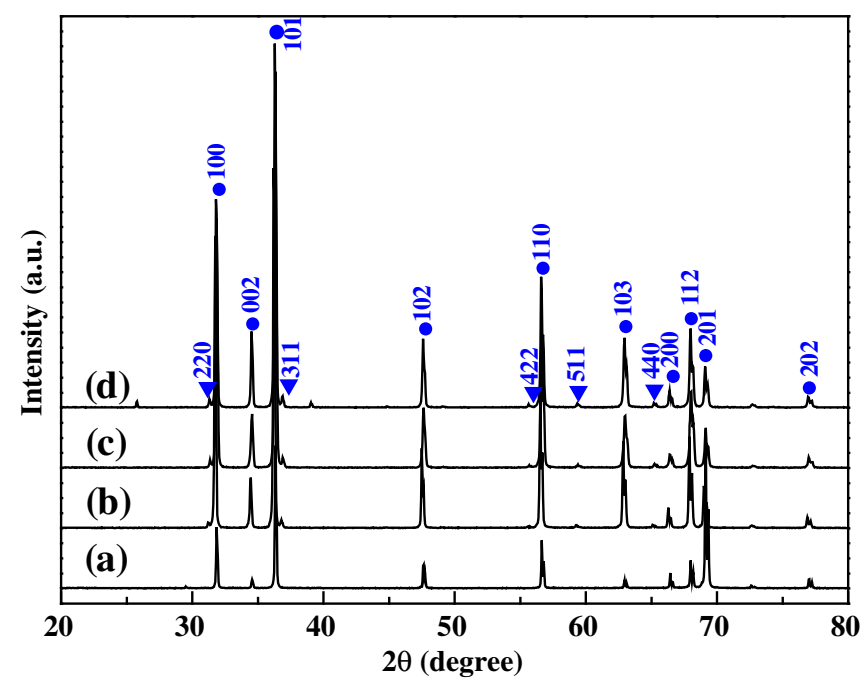

Figure 3. $\mathrm{XRD}$ spectra of microstructure in $\mathrm{ZnO}-\mathrm{Al}_{2} \mathrm{O}_{3}$ system sintered at $1500^{\circ} \mathrm{C}$ for $6 \mathrm{~h}$ : (a) pure $\mathrm{ZnO}$; (b) doped, $\mathrm{Al}_{2} \mathrm{O}_{3}=$ $1.5 \mathrm{wt} \%$; (c) doped, $\mathrm{Al}_{2} \mathrm{O}_{3}=2 \mathrm{wt} \%$ and (d) doped, $\mathrm{Al}_{2} \mathrm{O}_{3}=$ $2.5 \mathrm{wt} \%$. (• represents $\mathrm{ZnO}$ and $\boldsymbol{\Delta}$ represents $\mathrm{ZnAl}_{2} \mathrm{O}_{4}$ spinel).

figure 4(a), showing that the $\mathrm{ZnAl}_{2} \mathrm{O}_{4}$ spinel second phase existed at grain boundaries. The inhibition of $\mathrm{ZnO}$ grain growth resulted from $\mathrm{ZnAl}_{2} \mathrm{O}_{4}$ spinel phase located at grain boundaries or triple junctions, i.e. grain drag effects. Hence, the driving force of boundary mobility was reduced. It was found that residual pores in pure $\mathrm{ZnO}$ were mostly trapped in the grains and those in the $\mathrm{Al}_{2} \mathrm{O}_{3}$-doped $\mathrm{ZnO}$ samples were located at grain boundary or triple junctions, as shown in figure 2. The existence of porosity may also induce an electron scattering effect on the electric resistivity.

Table 2 shows the relative density and resistivity of undoped and doped $\mathrm{ZnO}$ sintered specimens with various $\mathrm{Al}_{2} \mathrm{O}_{3}$ contents. Increasing the $\mathrm{Al}_{2} \mathrm{O}_{3}$ content from 0 to $2 \mathrm{wt} . \%$ slightly raises the relative density of ceramic from 99.8\%-99.9\%. However, the relative density of ceramic with 2.5 wt. $\% \mathrm{Al}_{2} \mathrm{O}_{3}$ addition decreased to $98.4 \%$. The amount of $\mathrm{ZnAl}_{2} \mathrm{O}_{4}$ spinel second phase also increases when the $\mathrm{Al}_{2} \mathrm{O}_{3}$ content increases to $2.5 \mathrm{wt} . \%$ as shown in figure 3 . The $\mathrm{ZnAl}_{2} \mathrm{O}_{4}$ spinel second phase located at grain boundaries and triple junctions can induce a grain drag effect and hence reduce the driving force of boundary mobility, i.e. densification of the doped $\mathrm{ZnO}$.

The resistivity decreased from $331.1 \times 10^{-3}$ to $1.5 \times$ $10^{-3} \Omega$-cm when the amount of $\mathrm{Al}_{2} \mathrm{O}_{3}$ was increased to $2 \mathrm{wt} . \%$. The two orders of magnitude reduction of resistivity is due to the trivalent $\mathrm{Al}$ ions dissolved in $\mathrm{ZnO}$, which act as a shallow donor (Tang and Cameron 1994). In general, the electrical properties of AZO ceramics are quite related to the microstructures, which might be governed by crystallographic defects, e.g. grain boundary, stacking fault, twin, and dislocation (Sieber et al 1998; Lin et al 2009; Thonke et al 2009; Liu et al 2010). The bright-field image (figure 4(b)) shows the dominant crystallographic defect of

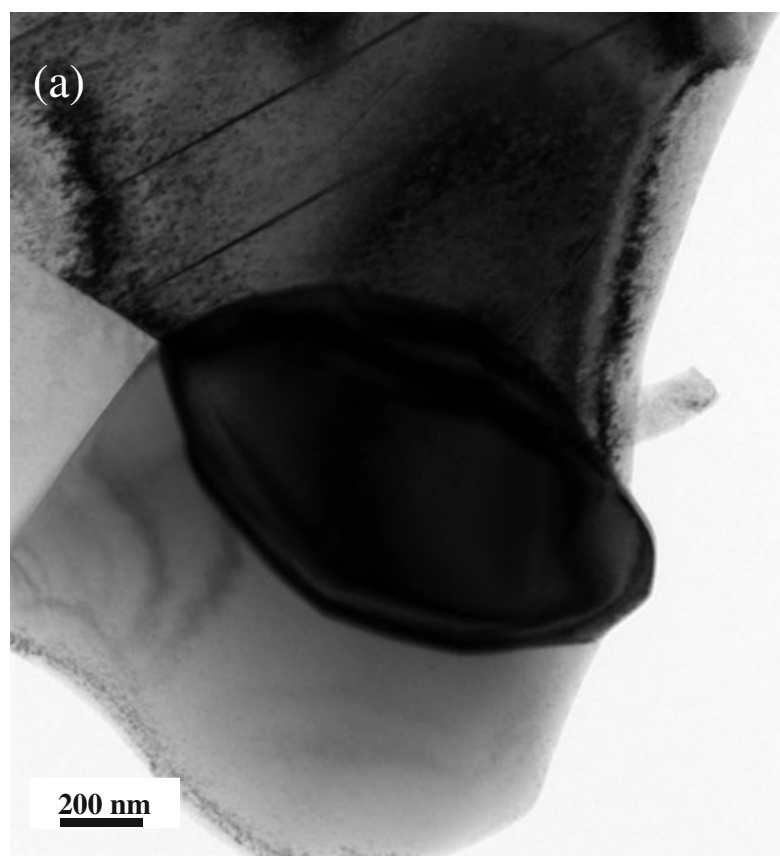

(b)

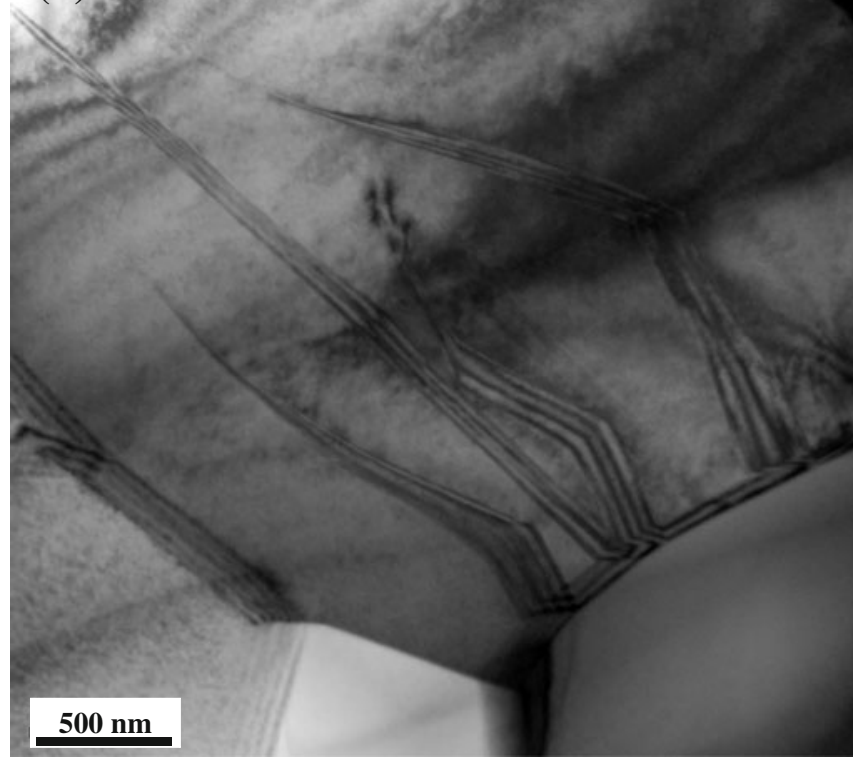

Figure 4. TEM bright-field micrographs of doped- $\mathrm{Al}_{2} \mathrm{O}_{3} \mathrm{ZnO}$ $\left(\mathrm{Al}_{2} \mathrm{O}_{3}, 2 \mathrm{wt} \%\right)$ ceramic sintered at $1500^{\circ} \mathrm{C}$ for $6 \mathrm{~h}$ : (a) $\mathrm{ZnAl}_{2} \mathrm{O}_{4}$ spinel and (b) stacking faults.

Table 2. Resistivity and relative density of $\mathrm{ZnO}$ sintered specimens with various $\mathrm{Al}_{2} \mathrm{O}_{3}$ contents.

\begin{tabular}{lrrrr}
\hline Components & $\mathrm{ZnO}$ & $\mathrm{ZnO}$ & $\mathrm{ZnO}$ & $\mathrm{ZnO}$ \\
\hline Doped- $\mathrm{Al}_{2} \mathrm{O}_{3}(\mathrm{wt} \%)$ & 0 & $1 \cdot 5$ & $2 \cdot 0$ & $2 \cdot 5$ \\
Resistivity $\left(\times 10^{-3} \Omega\right.$-cm) & $331 \cdot 1$ & $4 \cdot 1$ & 1.5 & 3.5 \\
Relative density $(\%)$ & 99.8 & $99 \cdot 8$ & 99.9 & $98 \cdot 4$ \\
\hline
\end{tabular}




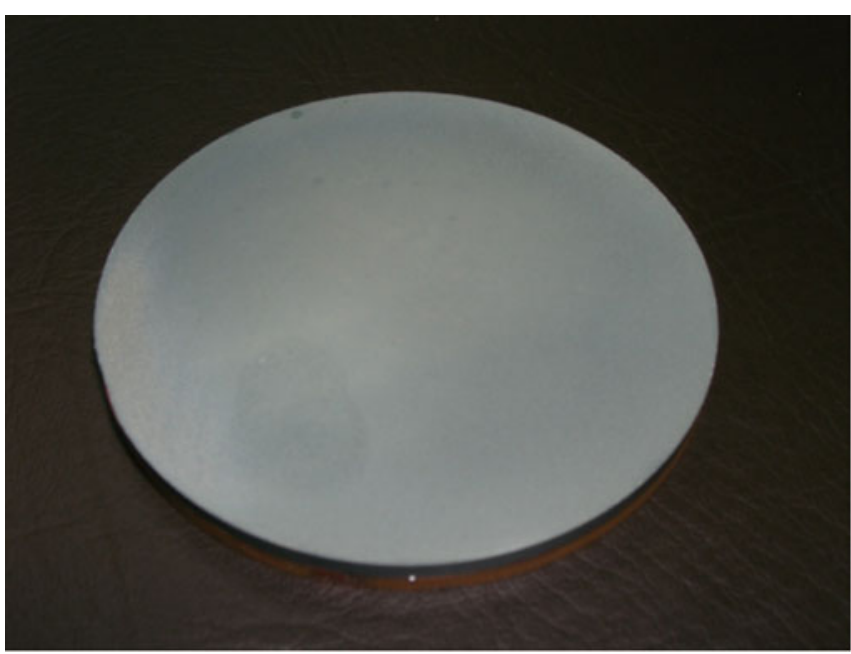

Figure 5. Photograph of 3-inch AZO ceramic target.

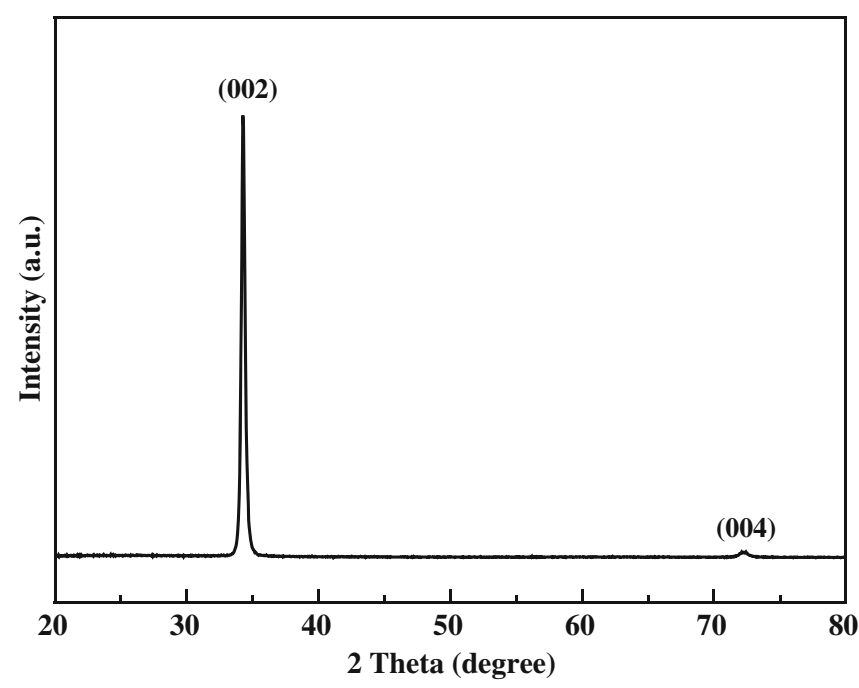

Figure 6. XRD diffraction pattern of AZO thin film.

stacking fault in the $\mathrm{Al}_{2} \mathrm{O}_{3}$-doped $\mathrm{ZnO}$. It has been reported that the incorporation of group-III or group-V dopants into the matrix apparently increases the tendency to create stacking fault resulting from the dislocation or the lattice misfit (Lin et al 2009; Sieber et al 1998; Thonke et al 2009; Liu et al 2010). Compared with the undoped and doped $\mathrm{ZnO}$, the 2.5 wt. $\% \mathrm{Al}_{2} \mathrm{O}_{3}$ doped $\mathrm{ZnO}$ has a lower density than the others, indicating that the sintered bulks contain more pores, as shown in figure 2(d). The porosity may result in more electron scattering effect and consequently a high resistivity for the 2.5 wt. $\% \mathrm{Al}_{2} \mathrm{O}_{3}$ doped $\mathrm{ZnO}$.

\subsection{Thin film deposition}

According to the effect of different $\mathrm{Al}_{2} \mathrm{O}_{3}$ content to the electrical and structural properties of $\mathrm{ZnO}$ ceramic, we found that

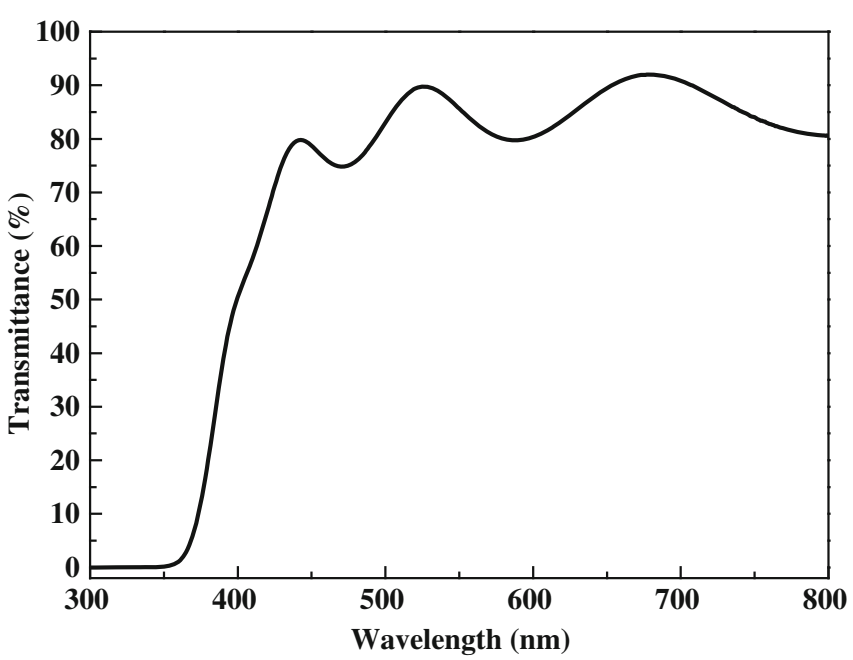

Figure 7. Optical transmittance spectra of AZO thin film.

the 2 wt. $\% \mathrm{Al}_{2} \mathrm{O}_{3}$ doped $\mathrm{ZnO}$ target has highest relative density and lowest electrical resistivity. Hence, we use this optimum condition of preparing 3 inch AZO target for thin film deposition.

Figure 5 shows the optical image of the 2 wt. $\% \mathrm{Al}_{2} \mathrm{O}_{3}$ doped AZO target with a diameter of 3 inch. The relative density and resistivity of AZO target were $99.8 \%$ and $1.8 \times$ $10^{-3} \Omega$-cm, respectively. Figure 6 illustrates the XRD pattern of AZO film deposited on the glass substrate. The AZO film had a preferred orientation along the (002) direction. Other peak (004) with much less intensity was also observed, indicating that the film has a preferred orientation with their $c$-axis perpendicular to the substrate plane. The grain size of AZO film which was evaluated using the Scherrer's equation is about $29.08 \mathrm{~nm}$. No $\mathrm{ZnAl}_{2} \mathrm{O}_{4}$ spinel second phase was found, implying that $\mathrm{Al}$ atoms substitute $\mathrm{Zn}$ in the hexagonal lattice and $\mathrm{Al}$ ions may occupy the interstitial sites of $\mathrm{ZnO}$. The resistivity, carrier density, and hall mobility of AZO film determined by hall measurement were $2.5 \times$ $10^{-3} \Omega$-cm, $1.04 \times 10^{20} \mathrm{~cm}^{-3}$ and $6.24 \mathrm{~cm}^{2} / \mathrm{Vs}$, respectively. The results revealed that the AZO film is degenerate $n$-type semiconductor. The transmittance of AZO film (the thickness of film is about $500 \mathrm{~nm}$ ) at $300-800 \mathrm{~nm}$ is given in figure 7. The AZO film exhibits an average transmittance of $90.3 \%$ in the visible region. According to the results of electrical and optical properties of AZO thin films, it revealed that the 2 wt. $\% \mathrm{Al}_{2} \mathrm{O}_{3}$-doped AZO target can be potentially applied for preparing transparent conductive oxide films. A more detailed study of the relationship between the thin films properties and the deposition parameters are underway.

\section{Conclusions}

The effects of $\mathrm{Al}_{2} \mathrm{O}_{3}$ addition on the grain growth, second phase formation, resistivity, and density of $\mathrm{ZnO}$ sintered by a solid state reaction technique were studied. The grain 
growth inhibition of $\mathrm{Al}$ doped- $\mathrm{ZnO}$ ceramics is attributed to the formation of $\mathrm{ZnAl}_{2} \mathrm{O}_{4}$ spinel second phase located at the grain boundaries and the grain triple junctions. The resistivity and relative density of the $2 \mathrm{wt} \% \mathrm{Al}_{2} \mathrm{O}_{3}$-doped AZO target with a diameter of 3 inch were $1.8 \times 10^{-3} \Omega$ $\mathrm{cm}$ and $99.8 \%$, respectively. High transparent and conductive AZO thin film has been obtained by RF magnetron sputtering from this ceramic target. The film demonstrated the optical transparency of $90.3 \%$ in the visible region and showed conductivity with electrical resistivity of $2.5 \times 10^{-3} \Omega-\mathrm{cm}$.

\section{References}

Ben Ayadi Z et al 2008 Mater. Sci. Eng. C28 613

Chatelon J P et al 1997 J. Sol-Gel Sci. Technol. 10185
Chopra K L et al 1983 Thin Solid Films 1021

Coutts T J et al 2000 J. Vac. Sci. Technol. A18 2646

Han J, Mantas P Q and Senos A M R 2001a J. Eur. Ceram. Soc. 21 1883

Han J, Mantas P Q and Senos A M R 2001b J. Mater. Res. 16 459

Jeong S et al 2003 Thin Solid Films 43578

Lin J C et al 2009 Thin Solid Films $\mathbf{5 1 7} 4715$

Liu K W et al 2010 J. Appl. Phys. 108043516

Rahaman M N 1995 Ceramic processing and sintering (New York: Marcel Dekker)

Sharma S K and Exarhos G J 1995 Thin Solid Films 27027

Sieber I et al 1998 Thin Solid Films 330108

Tang W and Cameron D C 1994 Thin Solid Films 23883

Thonke K et al 2009 Microelectron. J. 40210

Tominaga K et al 1999 Thin Solid Films 343-344 160

Zhang J et al 2006 J. Am. Ceram. Soc. 893874 